\title{
蕾受粉および温湯処理によるアジサイ種間雑種の自家不和合性打破
}

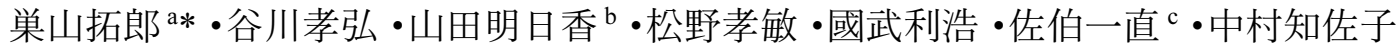 \\ 福岡県農業総合試験場８18-8549＼cjkstart福岡県筑紫野市大字吉木 587
}

\section{Overcoming Self-incompatibility by Bud Pollination and Hot-water Treatment in Interspecific Hybrids of Hydrangea}

\author{
Takuro Suyama ${ }^{\mathrm{a} *}$, Takahiro Tanigawa, Asuka Yamada ${ }^{\mathrm{b}}$, Takatoshi Matsuno, \\ Toshihiro Kunitake, Kazunao Saeki ${ }^{\mathrm{c}}$ and Chisako Nakamura \\ Fukuoka Agricultural Research Center, Chikushino, Fukuoka 818-8549
}

\begin{abstract}
Some Hydrangea macrophylla cultivars and interspecific H. macrophylla $\times H$. serrata hybrids are self-incompatible, making it difficult to breed them for recessive characters. To overcome self-incompatibility, pollinating at different flowering stages and hot-water treatments of the inflorescences were conducted using '03NL3', an interspecific H. macrophylla $\times$ H. serrata hybrid. Pollen tube growth was examined by fluorescence microscopy. At 3 days after pollination, the pollen tubes in flowers pollinated at 2 and 4 days after anthesis failed to reach the ovules. However, the pollen tubes were longer in styles pollinated 1 day before anthesis, and some had reached the ovules. For hot-water treatments, inflorescences were immersed in hot water $\left(45^{\circ} \mathrm{C}\right)$ for 1-5 min before self-pollination. The 3- to 4-min treatments promoted pollen tube growth. Selfed ovules were obtained by bud pollination, hot-water treatment $\left(45^{\circ} \mathrm{C}\right.$ water for $\left.4 \mathrm{~min}\right)$ of the inflorescences, and the combination of both treatments. Fertilized ovules were cultured in 1/2 MS medium and then grown in a greenhouse. At least half of these plants flowered within 2 years after self-pollination. The combination of bud pollination and hot-water treatment yielded the highest rate of selfed individuals.
\end{abstract}

Key Words : pollen tube growth, selfed individual, self-pollination

キーワード：自家受粉，自殖個体，花粉管伸長

\section{緒言}

ハイドランジアは，我が国に拈いて重要な鉢物栽培品目 のひとつであり，民間育種家や種苗会社などにより，多数 の品種が作出されている (末留, 1996). 近年, 観賞価值の 高い八重咲きや覆輪执よび手まり咲きの品種育成が盛んに 行われている（清水，2002; 巣山ら，2009）. 八イドランジ アの八重咲きは遺伝的に劣性形質であり（巣山ら，2008a）, 八重咲き品種のほとんどが雄ずいを持たない，従って，八 重咲き品種を育成するには, 八重咲き品種と一重咲き品種 の交雑をしなければならないが，雑種第 1 代では八重咲き は発現しない，八重咲き個体を獲得するためには，八重咲 き品種由来の雑種第 1 代の自家受粉などを行い, 雑種第 2

2013 年 2 月 7 日 受付. 2013 年 6 月 4 日 受理. 本研究の一部は園芸学会平成 19 年度秋季大会で発表した.

* Corresponding author. E-mail: t-suyama@farc.pref.fukuoka.jp

a 現在 : 福岡県農業総合試験場果樹苗木分場

福岡県久留米市田主丸町石垣 16-3

b 現在 : 福岡県飯塚農林事務所田川普及指導センター

c 現在 : 福岡県筑後農林事務所八女普及指導センター
代を得る必要がある（巣山ら，2012）。 また，花序の手まり 咲きについても, 単一の遺伝子に制御されたメンデル遺伝を 示す劣性形質であることが明らかにされている (Uemachi・ Okumura, 2012）。従って, 額咲き品種と手まり咲き品種の 交雑により手まり咲き品種を育成するには，八重咲き品種 と同様に，雑種第 2 代を得る必要がある.

ハイドランジアの自家和合性について, 工藤・新見 (1999) は Hydrangea macrophylla (Thunb.) Ser.（和名：ガクアジサ イ）“ブルーダイヤモンド’などの品種を自家受粉すること により種子が得られ，自家和合性を示したと報告している. 一方, Reed (2005) は, H. macrophylla の種内交雑系統や, この H. macrophylla と H. serrata (Thunb.) Ser. (和名 : ヤマ アジサイ）との種間雑種系統は自家不和合性を示したと報 告している. ハイドランジアに拈いても, チューリップ(志 佐ら，1955）と同様に，同一種内で自家和合性系統と自家 不和合性系統が混在することが明らかにされている。 この ハイドランジアの一部の系統が示す自家不和合性は, 八重 咲きなど優良劣性形質を持つ品種育成を行う際の障壁と なっている，従って，自家不和合性打破技術を確立するこ とは，優良劣性形質を持つ品種の効率的な育成および遺伝 
様式解明に寄与できると考兄られる.

Reed（2005）は，ハイドランジアの自家不和合性の要因 について, 他家受粉では花粉管が受粉後 3 日以内に肧珠に 到達するのに対し, 自家受粉では花粉管が花柱の途中で伸 長を停止し, 肧珠に到達できないために受精しないと報告 している.

花き類の自家不和合性を打破する技術として，ペチュニ アでは開花約 5 日前の蕾受粉が有効である（福本ら，1996） こと, ユリでは開花 $6 \sim 9$ 日後の老花受粉が有効である (Ascher・Peloquin, 1966) ことが報告されている. また, $50^{\circ} \mathrm{C}$ の温湯浸漬処理がマッヨイグサ，ユリ拈よびチューリップ の自家不和合性打破に有効であると報告されている (Hecht, 1964; Hopper ら， 1967; 岡崎・村上，1992).

本研究では, 八イドランジアの自家不和合性の要因であ る花柱内での花粉管の伸長抑制を打破するために，両性花 の異なる開花段階における受粉および受粉前の花序の温湯 処理を行い，自殖個体の獲得を試みた。

\section{材料および方法}

\section{1. 蕾・老花受粉による自家不和合性の打破（実験 1)}

H. serrata '七変化' と H. macrophylla ‘ラブューキッス' の種間雑種である自家不和合性系統 ‘03NL3’を供試し， 他家受粉の花粉親として H. macrophylla'ブルーダイヤモン ド’とH. serrata ‘七変化” の種間雑種系統 ‘03BN1’を供 試した. 福岡県農業総合試験場内のミストハウスに掻いて, 2006 年 4 月 25 日に挿し木を行い, 5 月 30 日に $9 \mathrm{~cm}$ 径ポリ ポットに鉢上げをした，巣山ら（2010）の手法に準じ，花 成誘導のための $15^{\circ} \mathrm{C}$ の涼温処理を 7 月 22 日〜 月 19 日 まで 60 日間行った後に, 休眠打破のための $5^{\circ} \mathrm{C}$ の低温処 理を 9 月 20 日〜 11 月 10 日まで 52 日間実施した. 11 月 11 日に $12 \mathrm{~cm}$ 径プラスチックポットに鉢替光後, 夜間最低気 温 $13^{\circ} \mathrm{C}$ に加温したガラス八ウスで管理した。 2007 年 1 月 4 日〜 3 月 30 日まで, 茨城県つくば市の農研機構果樹研究 所にある昼夜温 $20^{\circ} \mathrm{C}$ 一定の自然光型ファイトトロン内で 管理した.

‘03NL3’ の開花株を用い, 2007 年 1 月 $16 〜 23$ 日にか けて，蕾受粉および老花受粉を行った. 蕾受粉は翌日開花 すると推測される両性花の蕾の花弁抢よび葯をピンセット で除去後, 同一株の別の花序にある開花当日の両性花の花 粉を用いて自家受粉した. 老花受粉は開花前日に除雄後, 開花 2 日（花弁落下開始期）もしくは 4 日後に, 蕾受粉と 同様に自家受粉した. また, 対照区として開花当日に自家 受粉を実施した. 併せて, 開花当日の '03NL3' の両性花 に ‘03BN1’ の花粉を受粉する他家受粉を行った. いずれ の処理区も 10 個ずつ処理を行い, 花序全体を三角コーナー 用不織布水切りネットで二重被覆した.

受粉 3 日後の両性花を採取し,アスピレーターによる減圧 下でFAA $[70 \%$ エタノール: ホルマリン: 酶酸 $=18: 1: 1(\mathrm{v} /$ $\mathrm{v} / \mathrm{v})$ ] 液に約 4 時間浸漬した後, FAA 液の交換を行い引き続
き室温下で一晚浸漬して固定した. 蛍光顕微鏡観察用プレパ ラートを作成するに当たり，固定した両性花を流水で 1 時間 水洗した. 次に $1 \mathrm{~N}$ 水酸化ナトリウム水溶液に 5 時間浸漬 し, 組織を軟化させた後, 流水で 1 時間水洗した. 実体顕微 鏡下で花托を除去して，子房を心皮ごと（約 3 個）に分割し た後，アニリンブルー溶液（2\%リン酸三カリウム溶液にア ニリンブルーを $0.01 \%$ 溶解）に 16 時間浸漬し, 蛍光染色を 行った，染色した雌ずいをスライドガラスの上に並べ，カ バーガラスで押しつぶし，50\%グリセリンで封入した。

作成したプレパラートを落射照明装置（励起法：U 励起, AX, OLYMPUS) で蛍光させ, 顕微鏡 (AX70, OLYMPUS) で花柱扣よび子房内での花粉管伸長を観察した．各処理区 とも 5 個の両性花を供試し, 計 15 個の心皮についてプレパ ラートを作成して，花柱拈よび子房内で最も伸長している 花粉管の長さをミクロメータ（OLYMPUS）で測定した.

\section{2. 花序の温湯処理による自家不和合性の打破（実験 2)}

材料打よび栽培方法は実験 1 と同様とした。“03NL3’の 開花株を用い, 2007 年 1 月 $22 \sim 26$ 日にかけて, 花序の温 湯処理を行った．温湯処理前日の夕方，既に開花している 両性花をすべて除去した，処理当日，花序全体を恒温漕内 の $50^{\circ} \mathrm{C}$ の温湯に $1 ， 3 ， 5$ 分間, あるいは $45^{\circ} \mathrm{C}$ の温湯に 1 , 2，3，4，5 分間浸漬した. 温湯に浸漬してから約 30 分後 に, 開花当日の両性花の柱頭表面が乾いていることを確認 し, 温湯処理をしていない花序の開花当日の両性花の花粉 を用いて自家受粉を行った．対照区として，温湯処理を行 わない花序について, 開花当日の両性花の自家受粉を行っ た.いずれの処理区も 10 個ずつ処理を行い, 花序全体を不 織布水切りネットで二重被覆した．花粉管の染色拈よび観 察は実験 1 と同様に行った.

\section{3. 自家不和合性打破処理による自殖個体の獲得（実験 3）}

'03NL3’ および H. macrophylla ‘城ヶ崎” と種間雑種系統 ‘03BN4'（H. macrophylla ‘ブルーダイヤモンド’ × H. serrata “七変化'）の交雑により得られた自家不和合性系統 ‘05JBN4’を供試した。福岡県農業総合試験場内のミスト 八ウスに扎いて, 2006 年 4 月 25 日に挿し木を行った. 5 月 30 日に $9 \mathrm{~cm}$ 径ポリポットに鉢上げした後, 2007 年 4 月 10 日に $12 \mathrm{~cm}$ 径プラスチックポットに鉢替えをした. 2007 年 5〜6月に開花するまでのすべての栽培期間中, 温度成り 行きのガラスハウス内で管理を行った.

2007 年 5 月 $29 \sim 31$ 日にかけて, ‘03NL3’ の開花株を 用い, 実験 1 および 2 と同様に, 開花前日の蕾受粉打よび $45^{\circ} \mathrm{C}$ の温湯に花序を 4 分間浸漬した後に開花当日の花の自 家受粉を行った．併せて, $45^{\circ} \mathrm{C}$ の温湯に花序を 4 分間浸漬 した後に開花前日の蕾受粉を行い（以下，蕾受粉＋温湯処 理), 対照区として温湯処理をしていない開花当日の花の自 家受粉を行った．各処理区 $20 \sim 30$ 個の両性花に自家受粉 を行い, 交雑 60 日後に, 朔果内の自殖胚を含有する肥大し た肧珠（以下，自殖肧珠）数抢よび自殖胚珠を含有する朔 果の交雑花数に対する割合（以下，自殖肧珠含有朔果率） 
を調査した，自殖肧珠の培養を巣山ら（2008b）の手法に準 じて行い, 培養 60 日後に発芽した自殖肧珠数を調査した. 草丈が $1 \mathrm{~cm}$ 以上に成長した自殖個体を 12 月 19 日に, バー ミキュライトを充填した $6 \mathrm{~cm}$ 径ポリポットに鉢上げし, $25^{\circ} \mathrm{C}, 16$ 時間日長, 照度 $3,500 \mathrm{~lx}$ （植物育成用蛍光灯）の 順化室内で養成した. 草丈が $10 \mathrm{~cm}$ 程度になった 2008 年 3 月 20 日に, $\mathrm{pH}$ 調整ピートモス: 田土 : 腐葉土 : パーライ ト = $3: 3: 3: 1(\mathrm{v} / \mathrm{v} / \mathrm{v} / \mathrm{v})$ の培養土を充填した $9 \mathrm{~cm}$ 径ポリ ポットに鉢替光し, 夜間最低気温 $15^{\circ} \mathrm{C}$ に加温したガラス 八ウス内で管理した. 4 月 30 日に暖房を終了した後, 温度 成り行きのガラスハウス内で栽培を行った. 7 月 25 日に $12 \mathrm{~cm}$ 径プラスチックポットに鉢替光を行い, 2009 年 5 〜 6 月の開花期まで引き続き温度成り行きのガラス八ウス内 で管理した。

‘05JBN4’ については，2007 年 6 月 7 日に，蕾受粉＋温 湯処理を 16 個の両性花に行い, 対照区として温湯処理をし ていない花序の開花当日の花の自家受粉を10個の両性花に 行った。. '03NL3' と同様に, 交雑 60 日後に自殖肧珠含有 朔果率打よび朔果内の自殖胚珠数を調査した。併せて, 自 殖胚珠の培養を行い, 培養 60 日後に発芽した自殖肧珠数を 調査した. 以後, $6 \mathrm{~cm}$ 径ポリポットに鉢上げした自殖個体 を, $9 \mathrm{~cm}$ 径ポリポット抢よび $12 \mathrm{~cm}$ 径プラスチックポット に鉢替えする培養土として, $\mathrm{pH}$ 未調整ピートモス：赤玉 土 : 腐葉土 : パーライト $=5: 3: 1: 1(\mathrm{v} / \mathrm{v} / \mathrm{v} / \mathrm{v})$ を用いた以 外は, ‘03NL3’ と同様に栽培管理を行った.

\section{結 果}

\section{1. 蕾・老花受粉による自家不和合性の打破}

開花当日受粉区（対照区）の花粉管長は $0.78 \mathrm{~mm}$ で，花 粉管は花柱の中央部で伸長を停止していた（第 1 表，第 1 図）。一方，蕾受粉区の花粉管長は $1.49 \mathrm{~mm}$ であり，対照 区の約 2 倍の伸長を示した。 また，供試した 5 個の両性花 のらち 2 個で, 数本の花粉管が肧珠へ到達した. 花粉管が 肧珠に到達した両性花の割合（以下，肧珠到達花率）は 40 \%であった. 一方, 開花 2 日後受粉区の花粉管長は $1.06 \mathrm{~mm}$ であり, 対照区と有意差は認められなかった. 開花 4 日後 受粉区の花粉管長は $1.16 \mathrm{~mm}$ であり, 対照区と比較して花 粉管の伸長は促進されたものの, 花粉管の肧珠への到達は 観察されなかった.

‘03BN1' の花粉を受粉した他家受粉区の花粉管長は $2.63 \mathrm{~mm}$ であり, すべての処理区の中で最も長かった（第 1 表, 第 1 図). 供試した 5 個の両性花すべてにおいて肧珠 に到達した花粉管が多数観察され，胚珠到達花率は $100 \%$ であった。

\section{2. 花序の温湯処理による自家不和合性の打破}

花序を $50^{\circ} \mathrm{C}$ の温湯で 3 分または 5 分間処理した区では, 処理後 1 週間以内に花序全体が萎孔，枯死した（データ 略). $50^{\circ} \mathrm{C}$ の温湯で 1 分間処理した区では, 萎れや枯死症 状は認められなかったが, 処理 10 日後より落花および落
第 1 表 ‘03NL3’ の自家受粉における蕾および老花受粉が花 粉管伸長に及湆す影響

\begin{tabular}{|c|c|c|c|c|}
\hline 交雑方法 & 処理区 & $\begin{array}{c}\text { 花粉管長 } \\
(\mathrm{mm})\end{array}$ & $\begin{array}{c}\text { 花柱長 }{ }^{\mathrm{z}} \\
(\mathrm{mm})\end{array}$ & $\begin{array}{c}\text { 肧珠 } \\
\text { 到達花率 } \mathrm{y} \\
(\%)\end{array}$ \\
\hline \multirow[t]{4}{*}{ 自家受粉 } & $\begin{array}{l}\text { 開花前日 } \\
\text { (蕾受粉) }\end{array}$ & $1.49 b^{x}$ & $1.58 \mathrm{~b}$ & 40 \\
\hline & $\begin{array}{l}\text { 開花 } 2 \text { 日後 } \\
\text { (老花受粉) }\end{array}$ & $1.06 \mathrm{~cd}$ & $1.76 \mathrm{~b}$ & 0 \\
\hline & $\begin{array}{l}\text { 開花 } 4 \text { 日後 } \\
\text { (老花受粉) }\end{array}$ & $1.16 b c$ & $2.15 \mathrm{a}$ & 0 \\
\hline & $\begin{array}{l}\text { 開花当日 } \\
\text { (対照区) }\end{array}$ & $0.78 \mathrm{~d}$ & $1.80 \mathrm{~b}$ & 0 \\
\hline 他家受粉 w & 開花当日 & $2.63 \mathrm{a}$ & $1.81 \mathrm{~b}$ & 100 \\
\hline 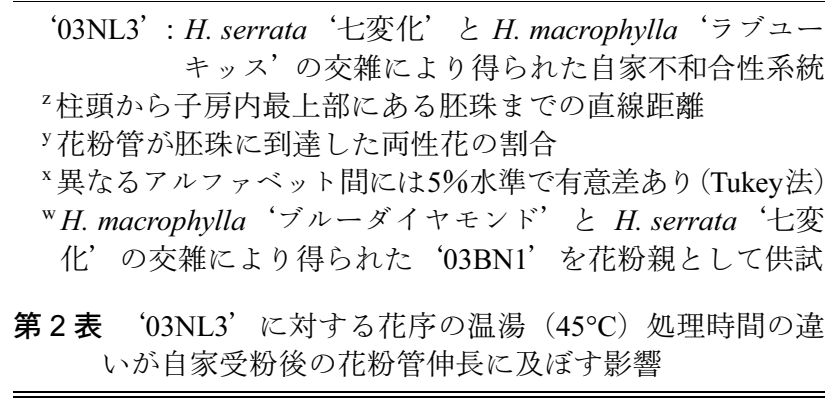 & \multicolumn{4}{|c|}{ 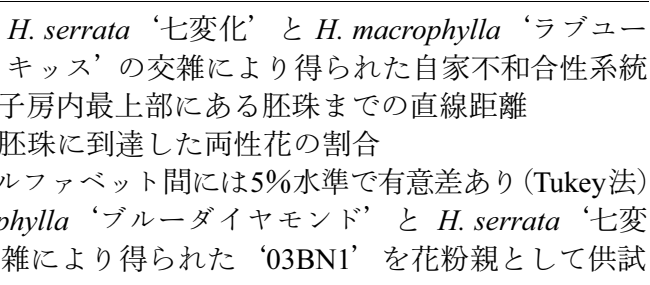 } \\
\hline 処理時間 & \multicolumn{2}{|c|}{$\begin{array}{c}\text { 花粉管長 } \\
(\mathrm{mm})\end{array}$} & $\begin{array}{l}\text { 苡柱長 }{ }^{z} \\
(\mathrm{~mm})\end{array}$ & $\begin{array}{c}\text { 肧珠 } \\
\text { 到達花率 } \mathrm{y} \\
(\%)\end{array}$ \\
\hline 1 分間 & \multicolumn{3}{|c|}{$1.18 \mathrm{ab}^{\mathrm{x}}$} & 0 \\
\hline 2 分間 & \multicolumn{2}{|c|}{$0.99 \mathrm{bc}$} & $.53 \mathrm{~b}$ & 0 \\
\hline 3 分間 & \multicolumn{2}{|c|}{$1.38 \mathrm{a}$} & $1.61 \mathrm{ab}$ & 20 \\
\hline 4 分間 & \multicolumn{2}{|c|}{$1.53 \mathrm{a}$} & $1.52 \mathrm{~b}$ & 40 \\
\hline 5 分間 & \multicolumn{2}{|c|}{$0.62 \mathrm{c}$} & $1.57 \mathrm{ab}$ & 0 \\
\hline 対照区 (0 分 & \multicolumn{2}{|c|}{$0.78 \mathrm{bc}$} & & 0 \\
\hline
\end{tabular}

${ }^{\mathrm{z}}$ 柱頭から子房内最上部にある肧珠までの直線距離

$\mathrm{y}$ 花粉管が肧珠に到達した両性花の割合

$\mathrm{x}$ 異なるアルファベット間には $5 \%$ 水準で有意差あり (Tukey法)

蕾が発生した。

一方, $45^{\circ} \mathrm{C}$ の温湯で処理した区では，いずれも萎れや落 花は発生しなかった. 1 分または 2 分間処理区の花粉管長 は $1.18 \mathrm{~mm}$ 打よび $0.99 \mathrm{~mm}$ であり, 対照区の $0.78 \mathrm{~mm}$ と比 較して有意な差は認められなかった (第 2 表)。これに対し て 3 分または 4 分間処理区の花粉管長はそれぞれ $1.38 \mathrm{~mm}$ および $1.53 \mathrm{~mm}$ であり, 対照区と比較して有意に長く花粉 管が伸長した。一部の両性花では数本の花粉管が肧珠に到 達し, 肧珠到達花率は 3 分間処理区が $20 \%$ であり，4 分間 処理区が $40 \%$ であった（第 2 表，第 1 図）。最も処理時間 の長い 5 分間処理区では，花柱内に侵入した花粉管はわず かであり, 花粉管長は $0.62 \mathrm{~mm}$ で対照区と有意な差は認め られなかった。

\section{3. 自家不和合性打破処理による自殖個体の獲得}

‘03NL3' の開花当日受粉区（対照区）の自殖肧珠含有朔 果率は $0 \%$ であった (第 3 表)。一方, 蕾受粉区の自殖肧珠 


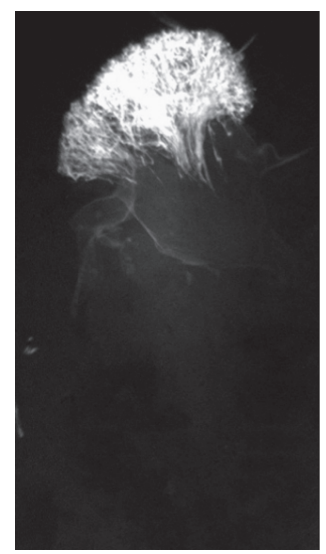

[開花当日受粉] （対照区）

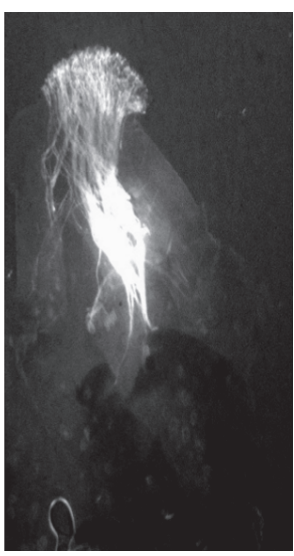

[蕾受粉]

(開花前日受粉)

自家受粉

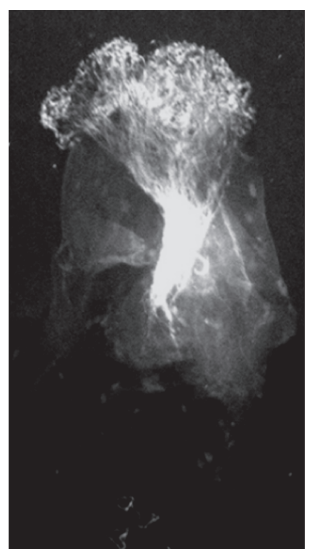

[温湯処理]

$\left(45^{\circ} \mathrm{C}, 4\right.$ 分 $)$

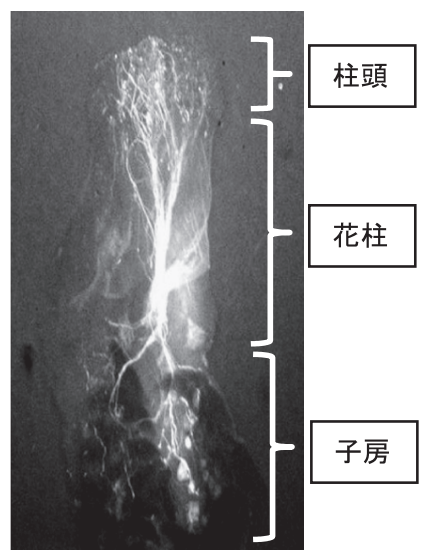

他家受粉

第 1 図 ‘03NL3’ に対する蕾受粉および花序の温湯処理が花柱内における花粉管伸長に及ぼす影響

第 3 表 ‘03NL3’および‘05JBN4’ に対する蕾受粉，花序の温湯処理，蕾受粉および温湯処理の組み合わせ処理が自殖肧珠の獲 得数および発芽に及ぼす影響

\begin{tabular}{|c|c|c|c|c|c|c|}
\hline 供試系統 & 処理区 & 交雑花数 & 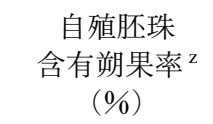 & $\begin{array}{l}\text { 朔果 } 1 \text { 果当たり } \\
\text { の自殖胚珠数 }{ }^{\mathrm{y}}\end{array}$ & 培養胚珠数 & 発芽肧珠数 ${ }^{\mathrm{x}}$ \\
\hline \multirow{4}{*}{ '03NL3’ } & 蕾受粉 ～～～～～～ & 30 & 47 & $4.4 \pm 3.8^{\mathrm{v}} \mathrm{b}^{\mathrm{u}}$ & 61 & 8 \\
\hline & 温湯処理 $\left(45^{\circ} \mathrm{C}, 4\right.$ 分間) & 22 & 91 & $3.5 \pm 2.2 \mathrm{~b}$ & 70 & 16 \\
\hline & 蕾受粉 + 温湯処理 & 20 & 85 & $11.7 \pm 8.1 \mathrm{a}$ & 199 & 77 \\
\hline & 対照区 ${ }^{\mathrm{w}}$ & 20 & 0 & - & - & - \\
\hline \multirow{2}{*}{ ‘05JBN4’ } & 蕾受粉 + 温湯処理 & 16 & 100 & $9.2 \pm 3.3$ & 147 & 95 \\
\hline & 対照区 ${ }^{w}$ & 10 & 0 & - & - & - \\
\hline \multicolumn{7}{|c|}{ 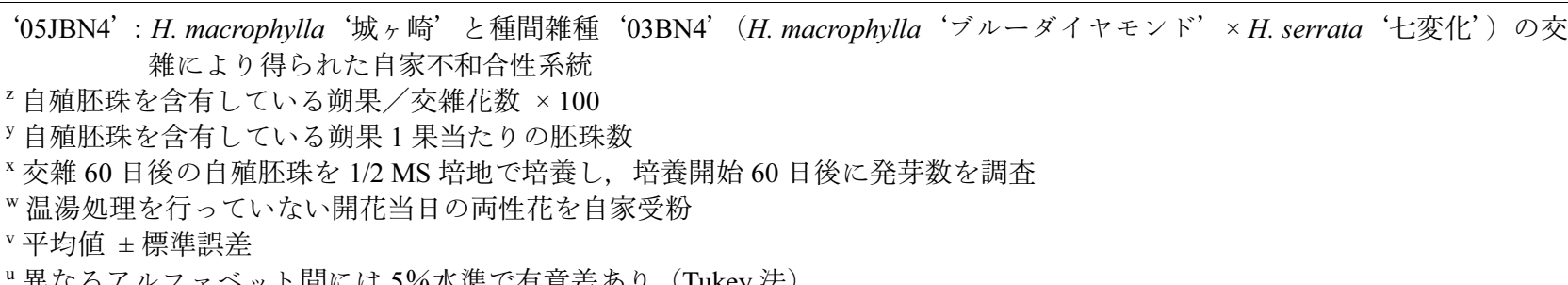 } \\
\hline
\end{tabular}

第 4 表 自家不和合性打破処理により獲得した ‘03NL3’ および ‘05JBN4’ の自殖個体の開花

\begin{tabular}{|c|c|c|c|c|}
\hline 供試系統 & 処理区 & 自殖個体数 ${ }^{\mathrm{z}}$ & 開花個体数 & $\begin{array}{c}\text { 開花期y } \\
\text { (年／月／日) }\end{array}$ \\
\hline \multirow{3}{*}{ ‘03NL3’ } & 蕾受粉 & 3 & 1 & $2009 / 5 / 29$ \\
\hline & 温湯処理 $\left(45^{\circ} \mathrm{C}, 4\right.$ 分間 $)$ & 7 & 3 & $2009 / 5 / 22 \sim 6 / 3$ \\
\hline & 蕾受粉 + 温湯処理 & 40 & 19 & $2009 / 5 / 25 \sim 6 / 8$ \\
\hline ‘05JBN4’ & 蕾受粉＋温湯処理 & 59 & 38 & $2009 / 5 / 13 \sim 5 / 28$ \\
\hline
\end{tabular}

$\mathrm{z}$ 草丈が $1 \mathrm{~cm}$ 以上に成長した自殖個体数

y 各個体の最初に開花した花序の装飾花が完全に着色した日を開花日とした

含有朔果率は $47 \%$ であり, 自殖肧珠を含有している朔果 1 果当たりの肧珠数は 4.4 個であった. 温湯処理区の自殖肧 珠含有朔果率は $91 \%$ であり, 朔果 1 果当たりの自殖肧珠数 は3.5 個であった. 蕾受粉 + 温湯処理区の自殖肧珠含有朔 果率は $85 \%$ であり, 朔果 1 果当たりの自殖肧珠数は 11.7 個
と処理区の中で最も多かった. 培養開始 60 日後の自殖肧珠 の発芽数は, 蕾受粉区で 8 個, 温湯処理区で 16 個, 蕾受粉 +温湯処理区で 77 個であった. 但し，発芽した肧珠の一部 は途中で生育を停止した後に枯死するものもあり，草丈が $1 \mathrm{~cm}$ 以上に成長した自殖個体数は，蕾受粉区で 3 個体，温 


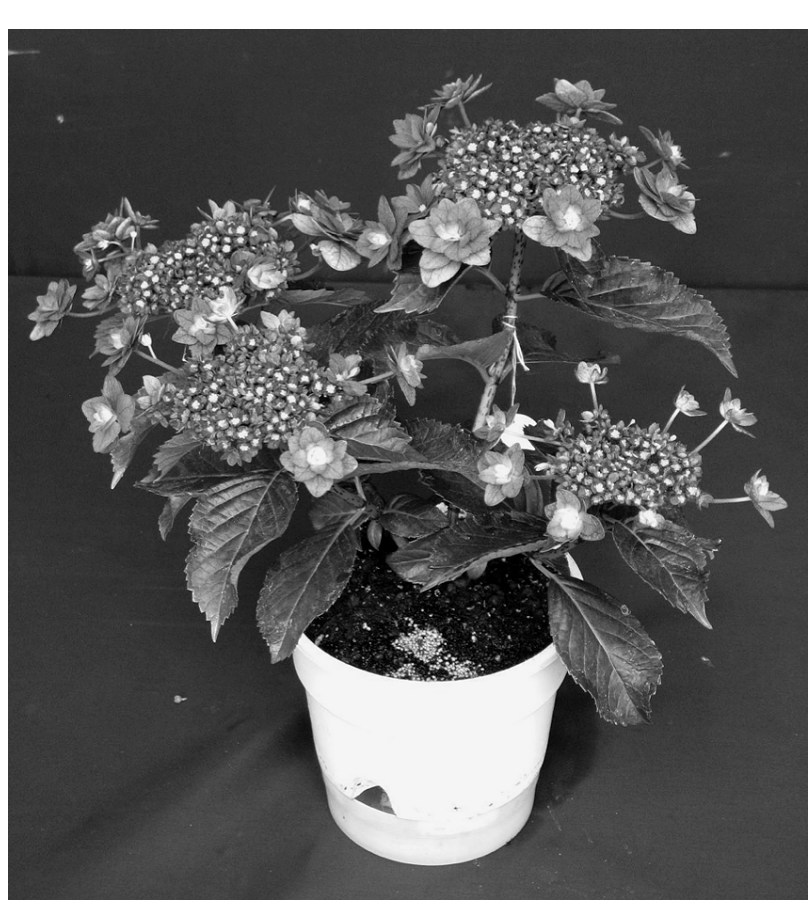

第 2 図自家不和合性打破処理により獲得した ‘05JBN4’の 八重咲き自殖個体

湯処理区で 7 個体，蕾受粉 + 温湯処理区で 40 個体であっ た (第 4 表)。これらの自家不和合性打破処理により得られ た自殖個体 50 個体のらち 23 個体が 2009 年 5 月 22 日〜 6 月 8 日にかけて開花した.

‘05JBN4’の開花当日受粉区（対照区）の自殖胚珠含有 朔果率は $0 \%$ であった (第 3 表). 一方, 蕾受粉 + 温湯処理 区の自殖肧珠含有朔果率は $100 \%$ であり, 朔果 1 果当たり の自殖肧珠数は 9.2 個であった. 培養開始 60 日後の自殖肧 珠の発芽数は95 個であったが, ‘03NL3’ と同様に発芽し た肧珠の一部は途中で生育を停止した後に枯死した．従っ て, 草丈が $1 \mathrm{~cm}$ 以上に成長した自殖個体数は 59 個体であっ た（第 4 表）。これら 59 個体のらち 38 個体が 2009 年 5 月 13〜28日にかけて開花した（第2 図).

\section{考察}

Reed (2005) はH. macrophylla の種内交雑およびH. macrophylla と H. serrata の種間雑種と H. macrophylla の交雑に 扣いて, 開花 $1 \sim 4$ 日後の両性花に他家受粉した花粉は 80 $\%$ 以上の発芽率を示し, 花粉管長は開花当日受粉区と同程 度であったと報告している. 一方, 開花 $5 \sim 6$ 日後の他家 受粉では，花粉の発芽率は $60 \%$ 未満で花粉管長は開花当日 受粉区の $1 / 2$ 以下であったと報告している. この結果は, 両性花の柱頭に打ける花粉の受容能力が開花 4 日後まで高 く, 雌ずいが受精能力を有していることを示している.従っ て, 本研究では, H. serrata と H. macrophylla の種間雑種で 自家不和合性を示す‘03NL3’ を用い, 開花 2 日または 4 日後の老花の段階で自家受粉を行った。開花 2 日後では,
対照区の開花当日受粉区と花粉管長に有意差は認められな かった. 一方, 開花 4 日後では花粉管の伸長は促進された ものの, 花粉管の肧珠への到達は全く観察されなかった. 但し, 開花 $5 \sim 6$ 日後の老花の段階に拈ける他家受粉でも 一定の花粉管伸長は観察されている（Reed, 2005）ことか ら, 今後は開花 $5 \sim 6$ 日後の老花受粉が自家不和合性打破 に有効かどらかについても，検討が必要と思われる.

Reed（2005）は，開花前日の蕾の段階に打ける 2 組の交 雑組又合わせの他家受粉を行ったところ，花粉管長は開花 当日受粉区の $1 / 2$ 程度もしくは全く伸長しなかったと報告 している.この結果は, 蕾の段階の柱頭における花粉の受 容能力が低いことを示しており，雌ずいの受精能力も同様 に低いと考えられた。しかし，本実験において開花前日の 蕾の段階で自家受粉を行ったところ，開花当日受粉区に比 べ花粉管長は約 2 倍になった．加えて，処理花の 40\%で花 粉管の肧珠への到達が観察され，蕾の段階の柱頭における 花粉の受容能力は高く，かつ雌ずいに受精能力があること が示された. 開花前日の蕾の柱頭に拈ける花粉の受容能力 (雌ずいの受精能力)に関する Reed と本実験結果の相違は, 自家不和合性に品種間差異がある（工藤・新見，1999; Reed， 2000, 2005）のと同様に, 品種間差異によるものであると考 穴れる。

受粉前の $50^{\circ} \mathrm{C}$ の温湯処理がマッヨイグサ，ユリおよび チューリップの自家不和合性打破に有効であると報告され ている（Hecht, 1964; Hopper ら， 1967; 岡崎・村上， 1992). しかし今回, ハイドランジアの花序を $50^{\circ} \mathrm{C}$ の温湯で 1 分, 3 分または 5 分間処理したが，いずれも枯死あるいは落花

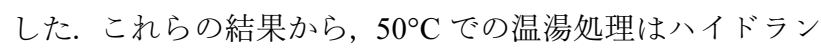
ジアに不適であることが明らかになった。 この $50^{\circ} \mathrm{C} の$ 温 湯処理は，ユリ扎よびチューリップでは柱頭のみに，マッ ヨイグサでは柱頭と花柱の上部のみに実施されている。一 方, ハイドランジアの両性花は花径が $1 \mathrm{~cm}$ 未満と極めて小 さいため，柱頭，花柱および子房を含めた両性花全体に実 施せざるを得なかった。. ハイドランジアに拈いても柱頭の みを処理することが可能ならば，今回と異なる結果が得ら れるかもしれない.

$45^{\circ} \mathrm{C}$ の温湯処理は処理時間に関係なく, 枯死や落花など の症状は全く認められなかった．花序全体を 1,2 分および 5 分間浸漬する処理では, 花粉管の伸長促進効果はなかっ た. 一方，花序全体を 3，4 分間浸漬処理することにより， 花柱内での花粉管伸長が促進され，処理花の 20，40\%で花 粉管が肧珠に到達した。配偶体型の自家不和合性を示すナ ス科のペチュニアやタバコなどでは，リボヌクレアーゼが 自家不和合性に関与することが明らかにされている (Huang ら，1994; McClure ら，1990）。また，同じ配偶体型の自家 不和合性を示すュリへの高温処理が自家不和合性を打破す る要因のひとつとして，花柱の細胞崩壊が考えられている (Hopper ら，1967）。加えて，胞子体型の自家不和合性を示 すアブラナ科のナタネに高温処理を行らと, 雌ずいの乳頭 
細胞の細胞膜に異常が発生し, 自家不和合性が打破される ことが報告されている（Okazaki・Hinata, 1987）。これらの ことから, 配偶体型の自家不和合性植物であるとされてい るハイドランジア（Reed, 2005）に打いて，本研究の 3, 4 分間の温湯処理は自家不和合性に関与するタンパク質の働 きを抑制したのではないかと考光られる. 花粉管伸長促進 効果のなかった 1,2 分間処理は, 不和合性に関与するタン パク質の抑制効果が弱く, 逆に 5 分間処理は不和合性に関 与するタンパク質以外の受精に必要なタンパク質の働きも 抑制した可能性がある.

蕾受粉と温湯処理を組み合わせることにより，それぞれ の単独処理よりも朔果内の自殖肧珠数は多くなった。 二小 ンナシでは, 自家不和合性が弱い蕾の段階に沶いて, 自家 不和合性に関与するタンパク質の生成量が少ないことが明 らかにされている (Hiratsuka ら, 1986). 従って, 本研究 に沏いても, 開花前日の蕾では自家不和合性に関与する夕 ンパク質の生成量が開花当日より少なかった可能性があ る. この開花当日よりも量が少ない自家不和合性に関与寸 るタンパク質の働きを温湯処理が抑制したことにより，相 乗的効果が得られたのではないかと考光られる.

蕾受粉, 温湯処理の単独処理打よび組み合わせ処理によ り得られた自殖個体は, 受粉から約 2 年後に開花した. こ れらの結果から，蕾受粉および温湯処理が H. macrophylla と H. serrataの雑種系統の自家不和合性打破に有効である ことが明らかになった. 今後, これらの自家不和合性打破 処理が遺伝様式の解明や劣性形質を目標とする育種の効率 化に寄与するものと考兄られる。

\section{摘 要}

H. macrophyllaやH. macrophylla と H. serrataの種間雑種に は自家不和合性を示す系統があり, 八重咲きなど劣性形質 を目標とする育種の障壁となっている. そこで H. macrophylla と H. serrata の種間雑種系統 ‘03NL3’を供試し, 異な る開花段階に打ける受粉処理や花序の温湯処理を行い, 自 家不和合性を打破する手法を検討した．開花 2 抢よび 4 日 後の両性花の自家受粉を行った後, 蛍光顕微鏡を用いて, 受粉 3 日後の花柱内における花粉管伸長を観察した. 開花 当日受粉区と比較して, 開花 2 日後の受粉では花粉管の伸 長促進効果はなかった. 開花 4 日後受粉では花粉管は有意 に伸長したものの, 胚珠に到達した花粉管は全くなかった. 一方, 開花前日の蕾受粉では, 開花当日受粉区と比較して, 花粉管は約 2 倍伸長し, 花粉管の一部は肧珠に到達した. また，花序全体を $45^{\circ} \mathrm{C}$ の温湯に浸漬する処理では，3 分ま たは 4 分間処理において花粉管伸長は促進され，花粉管の 一部は肧珠に到達した。‘03NL3’の蕾受粉, 花序の温湯処

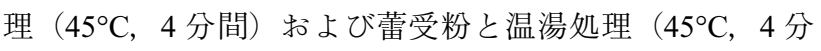
間) の組久合わせ処理により得られた交雑 60 日後の自殖肧 珠を $1 / 2 \mathrm{MS}$ 培地で培養した. 得られた自殖個体を施設内で 管理したところ, 約半数の個体が交雑 2 年後に開花した.
自殖個体の獲得率は，蕾受粉と温湯処理の組久合わせ処理 区で最も高かった。

謝辞 本研究を行うに当たり，ご指導，ご助言拉よび ご協力を頂きました（独）農業・食品産業技術総合研究機 構花き研究所の大宮あけ久博士，小野崎 隆博士，八木雅 史博士ならびに研究所の皆様, 果樹研究所の佐藤義彦様に 心より感謝致します。

\section{引用文献}

Ascher, P. D. and S. J. Peloquin. 1966. Effect of floral aging of the growth of compatible and incompatible pollen tubes in LiLium Longiflorum. Amer. J. Bot. 53: 99-102.

福本修一・青木千佳・服部一三. 1996.ペチュニアの蕾受 粉に打流花粉管の挙動観察と, 自家不和合性打破の 試及. 育学雑. 46 (別2)：252.

Hecht, A. 1964. Partial inactivation of incompatibility substance in the stigmas and styles of Oenothera. p. 237-243. In: H. F. Linskens (ed). Pollen physiology and fertilizaton. NorthHolland Publ. Comp., Amsterdam.

Hiratsuka, S., K. Ichimura, E. Takahashi and N. Hirata. 1986. Analysis of proteins in developing style and ovary with reference to self-incompatibility of Japanese pear. J. Japan. Soc. Hort. Sci. 55: 145-152.

Hopper, J. E., P. D. Ascher and S. J. Peloquin. 1967. Inactivation of self-incompatibility following temperature pretreatments of styles in LiLium Longiflorum. Euphytica 16: 215-220.

Huang, S., H. S. Lee, B. Karunanandaa and T. Kao. 1994. Ribonuclease activity of Petunia inflata $\mathrm{S}$ proteins is essential for rejection of self-pollen. Plant Cell 6: 1021-1028.

工藤暢宏・新見芳二. 1999. セイヨウアジサイとアメリカ ノリノキとの種間雑種の獲得に関する研究. 園学雑. 68: 428-439.

McClure, B. A., J. E. Gray, M. A. Anderson and A. E. Clarke. 1990. Self-incompatibility in Nicotiana alata involves degradation of pollen rRNA. Nature 347: 757-760.

Okazaki, K. and K. Hinata. 1987. Repressing the expression of self-incompatibility in crucifers by short-term high temperature treatment. Theor. Appl. Genet. 73: 496-500.

岡崎桂一・村上欣治. 1992. チューリップの自家不和合性 の打破に及ぼす開花時期ならびに柱頭切除および高温 処理の影響. 園学雑. 61: 405-411.

Reed, S. M. 2000. Compatibility studies in Hydrangea. J. Environ. Hort. 18: 29-33.

Reed, S. M. 2005. Pollination biology of Hydrangea macrophylla. HortScience 40: 335-338.

清水良泰. 2002. 品種・系統と栽培特性（アジサイ）。 p. 32-34. 農業技術大系 花卉編. 第 11 巻. 花木. 農文 協. 東京.

志佐 誠・万豆剛一・桜井 博・木村敬助. 1955. チュー 
リップの育種学的研究. p. 1-71. 志佐誠編著. 輸出球 根に関する研究. 誠文堂新光社. 東京.

末留 昇. 1996. 鉢物用ハイドランジアの品種とその特性. 新花卉. 169: 26-29.

巣山拓郎・谷川孝弘・山田明日香・松野孝敏・國武利浩.

2008b. Hydrangea serrata (Thunb.) Ser. ¿ Hydrangea macrophylla（Thunb.) Ser. との交雑親和性の解明と泼 珠培養による雑種獲得の効率化. 園学研. 7:337-343. 巣山拓郎・谷川孝弘・山田明日香・松野孝敏・國武利浩. 2009. 多花性のアジサイ新系統“福花 13 号’抢よび八 重・手まり咲き系統 “福花 14 号”, “福花 15 号” の育 成. 園芸学会九州支部研究集録. 17: 74 .
巣山拓郎 - 谷川孝弘・山田明日香 - 松野孝敏 - 國武利浩. 2010. 肧珠培養および開花調節によるアジサイ種間雑 種の育成年限短縮. 園学研. 9: 387-394.

巣山拓郎・谷川孝弘・山田明日香・佐伯一直 ・ 中村知佐子・ 國武利浩・松野孝敏. 2008a. ハイドランジア装飾花の 一重拉よび八重咲きの遺伝. 園学研. 7 (別2): 293.

巣山拓郎・谷川孝弘・山田明日香・佐伯一直 $・$ 中村知佐子 國武利浩・松野孝敏. 2012. 八イドランジア装飾花の 八重咲きの遺伝 (第2 報)。園学研. 11 (別 1)：189.

Uemachi, T. and A. Okumura. 2012. The inheritance of inflorescence types in Hydrangea macrophylla. J. Japan. Soc. Hort. Sci. 81: 263-268. 